\title{
Chironomidae (Diptera) community structure in two subsystems with different states of conservation in a floodplain of southern Brazil
}

\author{
Estrutura da comunidade de Chironomidae (Diptera) em dois subsistemas em \\ diferentes estados de conservação de uma planície de inundação do sul do Brasil
}

Gisele Cristina Rosin ${ }^{1}$, Danielle Paula de Oliveira Mangarotti ${ }^{1}$ and Alice Michiyo Takeda ${ }^{2}$

'Programa de Pós-graduação em Ecologia de Ambientes Aquáticos Continentais, Universidade Estadual de Maringá - UEM, Av. Colombo, 5790, Maringá, CEP 87020-900, PR, Brasil e-mail: giselerosin@hotmail.com, danipbio@yahoo.com.br

${ }^{2}$ Departamento de Biologia-Nupélia - PEA, Universidade Estadual de Maringá - UEM, Av. Colombo, 5790, Maringá, CEP 87020-900, PR, Brasil

e-mail: alicemtakeda@yahoo.com.br

\begin{abstract}
Aim: Our study aimed to compare the composition, distribution, diversity, abundance and dominance of Chironomidae in two subsystems of the Upper Paraná River floodplain, with different levels of conservation. We expected to find the highest values of diversity and lowest dominance of taxa in the most conserved areas (Ivinhema subsystem). We also expected to detect differences in the composition and distribution of communities between the subsystems, because of the level of conservation of each subsystem; Methods: Sampling was performed in March and September 2003, in eight stations, four in the Paraná River subsystem and four in the Ivinhema River subsystem. Four samples were taken at each point with a modified Petersen-type sampler: three for biological analysis and one for sedimentological analysis. Chironomidae larvae were identified to generic level; Results: Twenty-nine genera belonging to three subfamilies (Tanypodinae, Chironominae and Orthocladiinae) were recorded in this study. Chironomus, Dicrotendipes, Goeldichironomus, and Tanypus were the main genera found in the Paraná subsystem. Polypedilum was the only genus present in all sampling stations, and was dominant in five of them. In the Paraná subsystem we observed the highest values of dominance, and in the Ivinhema subsystem the largest number of rare taxa; Conclusions: Results showed differences in the structure of the Chironomidae community between the Paraná and Ivinhema subsystems. The community of Chironomidae in the Paraná subsystem was composed predominantly by generalist and tolerant genera. In the Ivinhema subsystem we observed higher richness of taxa. The greatest diversity, lowest values of dominance and exclusive taxonomic composition in the Ivinhema River subsystem could be reflecting a less degraded environment, demonstrating that the conservation of these areas is essential for maintaining the diversity of Chironomidae.
\end{abstract}

Keywords: Chironomidae larvae, anthropic influences, diversity, Paraná River, Ivinhema River.

Resumo: Objetivo: Esse estudo teve por objetivo comparar a composiçáo taxonômica, distribuição, diversidade, abundância e dominância da comunidade de Chironomidae em dois subsistemas da Planície de inundação do alto rio Paraná em diferentes estados de conservação. Esperava-se encontrar maiores valores de diversidade e menor dominância de táxons nas áreas mais conservadas (subsistema Ivinhema). Esperava-se também, diferenças na composição e na distribuição da comunidade entre os subsistemas devido a aos diferentes estados de conservação de cada estação; Métodos: As coletas foram realizadas em março e setembro de 2003 em oito ambientes, quatro no subsistema Paraná e quatro no subsistema Ivinhema. Em cada ponto foram coletadas quatro unidades amostrais por período com um pegador do tipo Petersen modificado: três para análise biológica e uma para análise sedimentológica. As larvas de Chironomidae foram identificadas no nível de gênero; Resultados: Foram registrados 29 gêneros pertencentes a três subfamílias de Chironomidae. Chironomus, Dicrotendipes, Goeldichironomus, e Tanypus foram os principais representantes do subsistema Paraná. Polypedilum foi o único gênero presente em todas as estaçóes de amostragem e dominante em cinco delas. No subsistema Paraná foram observados maiores valores de dominância e no subsistema Ivinhema maior número de espécies raras; Conclusóes: Os resultados demonstraram diferenças na estrutura da comunidade de Chironomidae entre os subsistemas Paraná e Ivinhema. A composição 
de Chironomidae no subsistema Paraná foi predominantemente de gêneros considerados generalistas e tolerantes. No subsistema Ivinhema foi observado maior riqueza de táxons. A maior diversidade no subsistema Ivinhema pode ser um reflexo de ambientes menos degradados, mostrando que a preservação dessas áreas é determinante para a manutenção da abundância e da diversidade de Chironomidae.

Palavras-chave: Larvas de Chironomidae, influências antrópicas, diversidade, Rio Paraná, Rio Ivinhema.

\section{Introduction}

The Upper Paraná River has drainage area of $891,000 \mathrm{~km}^{2}, 10.5 \%$ of the total area of Brazil. It flows South-Southwest, through the region with the highest population density in Brazil. In consequence, its water bodies have been severely affected by anthropogenic disturbances, such as biocides, household sewage and removal of riparian vegetation. However, dams are among the most damaging human activities in the basin (Agostinho et al., 2008).

Before the closure of the Porto Primavera Dam (closed in 1998), a large $480 \mathrm{~km}$ floodplain existed. Currently, this floodplain includes a stretch of $230 \mathrm{~km}$, from the Porto Primavera Dam to the upper part of the Itaipu Reservoir (Agostinho et al., 2008). The floodplain is a mosaic of habitats with peculiar characteristics, great heterogeneity of habitats and high biodiversity (Thomaz et al., 2004). This area, named the Upper Paraná River floodplain, is the last stretch of the Paraná River free of dams in Brazilian territory. However, regulation of the flow upstream can result in serious consequences for the structure and functioning of the floodplain. The flow regulation changes the transport of sediment (Rocha et al., 2001; Hayakawa, 2007), and this factor can directly affect the biota in consequence of physical, chemical, geomorphological and hydrological modifications (Agostinho et al., 2008).

Studies have shown that inflow from tributaries downstream of dams can lead to recovery of the altered composition of assemblages through changes in the substrate material and other habitat conditions (Storey et al., 1991; Stevens et al., 1997; Vinson, 2001)

The Ivinhema River is one of the main tributaries located at the right margin of the Paraná River. The Ivinheima subsystem is formed by the Ivinheima River and associated floodplain lakes (Pauleto et al., 2009). It has heterogeneous vegetation on its margins, ranging from herbaceous vegetation to the formation of extensive areas of riparian forests at different regeneration stages (Stevaux et al., 1997).
The Ivinheima River basin was not affected by the control imposed by dams and has more regular flood pulses when compared to the Paraná River (Abujanra et al., 2009). The Ivinhema River still displays relatively pristine conditions, which are little affected by the Paraná River, except for the exceptional floods, when the fluviometric level of the Paraná River is higher than $4.5 \mathrm{~m}$ (Souza-Filho et al., 2004).

Benthic macroinvertebrate communities are relatively rich in species, with large number of individuals, distributed in diverse habitats (Rosenberg and Resh, 1996). Therefore, the community composition is sensitive to the anthropogenic modification of habitats (Armitage and Pardo, 1995; Greenwood et al., 1999).

This community reflects some of the key processes of river ecosystems; we can use the distribution data of different groups in an aquatic basin to predict the status of the community and the ecosystem, based upon the assessment of community structure (Galdean et al., 2000). Among the benthic macroinvertebrate, Chironomidae larvae have particular ecological interest because they occur in a wide variety of habitats (Ferrington, 2008), as they are able to survive under several environmental conditions (Pinder, 1995)

Our study aimed to compare the composition, distribution, diversity, abundance and dominance of Chironomidae in two subsystems of the Upper Paraná River floodplain with different levels of conservation. We expected to find the highest values of diversity and the lowest dominance of taxa in the most conserved areas (Ivinhema subsystem). We also expected to find differences in the composition and distribution of the community between the subsystems due to the different levels of conservation of each subsystem.

\section{Material and Methods}

\subsection{Study area}

The Upper Paraná River basin occupies a wide area of approximately $802,150 \mathrm{~km}^{2}$ (Souza-Filho 
and Stevaux, 1997). The Upper Paraná River floodplain is located on the right margin of the Paraná River $\left(23^{\circ} 43^{\prime}-25^{\circ} 33^{\prime} \mathrm{S}\right.$ and $54^{\circ} 35^{\prime}-$ $\left.53^{\circ} 10^{\prime} \mathrm{W}\right)$, between the States of Mato Grosso do Sul and Paraná (Figure 1).

Our study was conducted in two subsystems of this floodplain: the Paraná River and the Ivinhema River. In each subsystem, four stations were selected and three sites at each station were established, two in the margins and one in the central region.

Selected stations in the Paraná River subsystem were: 1) main channel with mean flow of $0.30 \mathrm{~m} / \mathrm{s}$ and high transparency; 2) Pau Véio Backwater, a semi-lotic environment; 3) Garças Lake, a connected lake and; 4) Osmar Lake, a lake that is not connected.

Selected stations in the Ivinhema River subsystem were: 1) main channel with mean flow of $0.20 \mathrm{~m} / \mathrm{s}$ and low transparency; 2) Ipoitâ channel, a lotic environment that connects the Ivinhema River and the Paraná River; 3) Patos Lake, a connected lake and; 4) Ventura Lake, a lake that is not connected.

\subsection{Sampling and proceeding}

Sampling was performed in March and September 2003 with a modified Petersen-type sampler $\left(0.0345 \mathrm{~m}^{2}\right)$. Four sampling units were taken at each sampling point: three for biological analysis and one for sedimentological analysis. Depth was measured with Digital Sounder. Conductivity, $\mathrm{pH}$, water temperature, and dissolved oxygen content (mg. $\mathrm{L}^{-1}$ and saturation percentage) were recorded with a 6820-YSI device. Data on hydrometric levels were provided by ANA (Agência Nacional das Águas).

Sediment samples were dried in an oven at $80^{\circ} \mathrm{C}$. Granulometric texture was determined according to the Wentworth's scale (Wentworth, 1922), using the wet method. Organic matter content in the sediment was obtained by calcination of the sample in a muffle at $560{ }^{\circ} \mathrm{C}$, for approximately four hours.

The biological material was taken to NUPELIA's (Research Nucleus in Limnology Ichthyology and Aquaculture) research outpost, in the city of Porto Rico, State of Paraná, and washed through a set of sieves (2.0, 1.0, and $0.2 \mathrm{~mm}$ mesh). Organisms found in the 2.0 and $1.0 \mathrm{~mm}$ mesh sieves were immediately fixed in $70 \%$ alcohol. The material retained in the $0.2 \mathrm{~mm}$ mesh sieve was placed in polyethylene jars containing $70 \%$ alcohol, and then observed under the stereoscopic microscope.

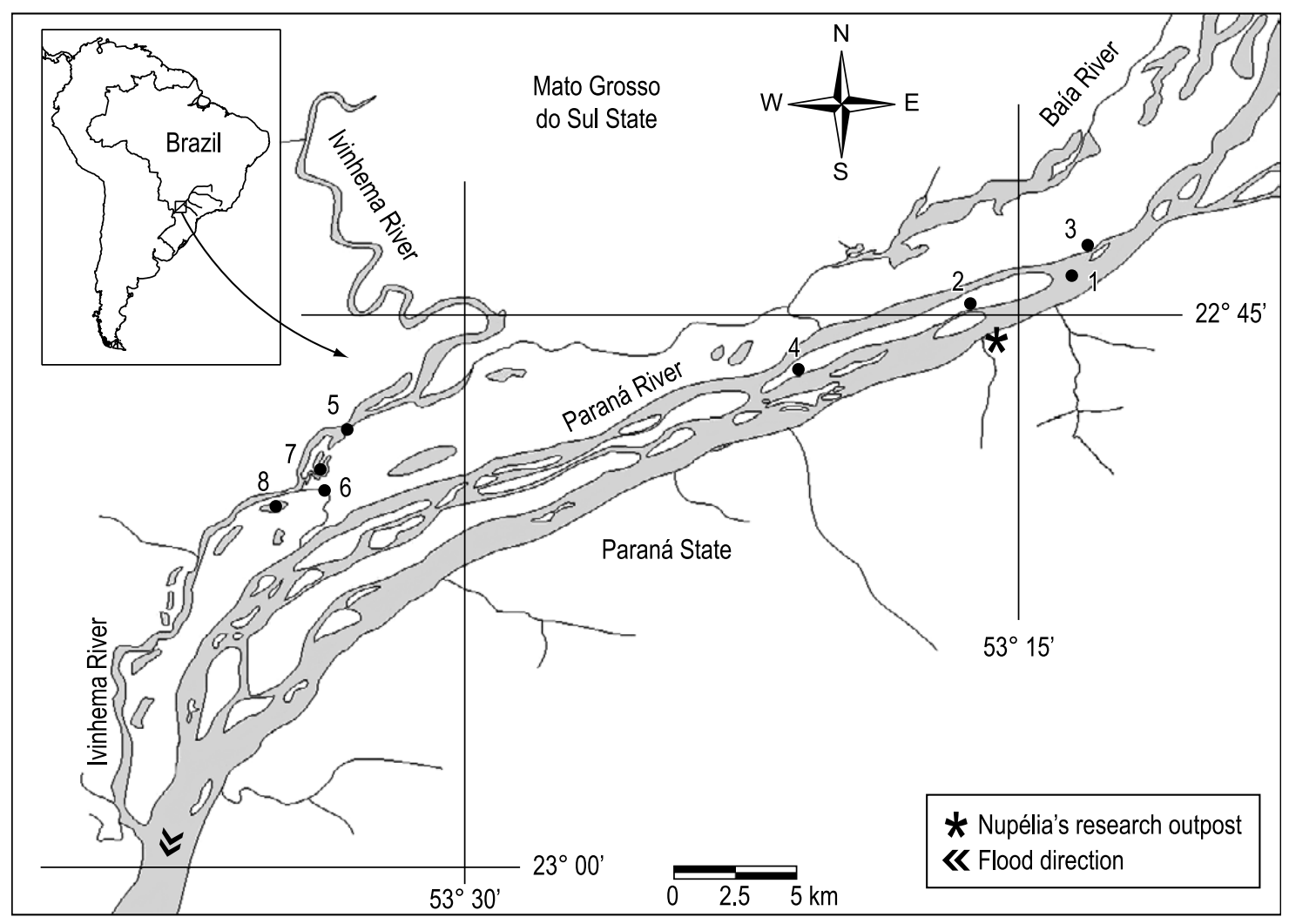

Figure 1. Study area and sampling sites. (1) Paraná River, (2) Pau Véio Backwater, (3) Garças Lake, (4) Osmar Lake, (5) Ivinhema River, (6) Ipoitã Channel, (7) Patos Lake, (8) Ventura Lake. 
The organisms found were separated into taxonomic groups for qualitative and quantitative analyses. Chironomidae larvae were identified to the genus level using identification keys, such as those by Epler (1995) and Trivinho-Strixino and Strixino (1995).

Principal Component Analysis (PCA) was used to reduce the dimensionality of the environmental variables and to rank stations and months in relation to the water temperature, depth, $\mathrm{pH}$, electric conductivity, dissolved oxygen, organic matter, pebbles, granules, very coarse sand, coarse sand, medium sand, fine sand, very fine sand and mud. The first two ordination axes were retained for interpretation using the Broken-Stick criterion. In order to verify differences in the PCA scores, twoway ANOVA was applied.

Kownacki's dominance index (Kownacki, 1971) was adapted for the genus category and calculated for the different environments and months according to the formula (Equation 1):

$\mathrm{d}=\frac{\tilde{\mathrm{Q}} \cdot 100}{\sum \tilde{Q}} \cdot \mathrm{f}$

were $\tilde{Q}=$ Average number of individuals of each genus recorded on a set of samples, $\Sigma \hat{Q}=$ sum of the quantity average of individuals of all genera, $\mathrm{f}=$ frequency, $\mathrm{n} / \mathrm{N}$, where $\mathrm{n}=$ number of samples representative of the species investigated and $\mathrm{N}=$ number of samples in the series.

The ordination of environments based on the composition and density of taxonomic groups was performed by the Detrended Correspondence Analysis (DCA). In order to carry out these analyses, the abiotic data were standardized and the biological data were normalized by log-transformation ( $\log$ $\mathrm{n}+1$ ). To verify differences in DCA scores, two-way ANOVA was applied.

The generic diversity analysis, addressing different aspects of each particular environment, was calculated using Shannon-Wiener's diversity index (Shannon and Weaver, 1963).

The PC-ORD software program (version 4.0) was used to run PCA and DCA, and the Statistica software (version 7.0) was used for other analyses.

\section{Results}

\subsection{Abiotic variables}

In the Paraná River, the high water period comprised the months from January to April, with peak of approximately $5 \mathrm{~m}$ in March. The low water period was observed between the months of May and November, with levels close to $2 \mathrm{~m}$ in June, August and November. The water levels of the Ivinhema River were little influenced by variations in the level of the Paraná River and did not follow the same patterns of oscillation (Figure 2).

The first two principal components analysis (PCA) axis accounted for $44.88 \%$ (28.08\% on axis 1 and $16.80 \%$ on axis 2) of the total variance of the physical and chemical variables. The two PCA axis separated environments and sampling months. The variables that contributed toward the formation of axis 1 separated the Pau Véio Backwater, Garças Lake, and Osmar Lake (Group I) from the other environments, especially because of their higher mud and organic matter percentages. Conversely, all the Ivinhema River subsystem and the Paraná River main channel (Group II) showed the greatest variety in granulometric texture (Figure 3). Significant differences were observed between groups I and II (Sampling stations* Months: $\mathrm{F}_{7,32}=2.64 ; \mathrm{p}=0.03$ ) (Figure 4).

In the ordination, axis 2 separated March from September because of the high temperature mean and low dissolved oxygen mean in March (Water temperature $=28.00^{\circ} \mathrm{C}, \pm 0.88$; Dissolved oxygen $\left.=4.33 \mathrm{mg} \cdot \mathrm{L}^{-1}, \pm 1.84\right)$ and low temperature mean and high dissolved oxygen mean in September (Water temperature $=22.23{ }^{\circ} \mathrm{C}, \pm 3.01$; Dissolved oxygen $=7.19 \mathrm{mg} . \mathrm{L}^{-1}, \pm 2.33$ ) (Figure 3 ), but significant differences were not observed (Sampling stations* Months: $\mathrm{F}_{7,32}=0.24 ; \mathrm{p}=0.27$ ) (Figure 4).

\subsection{Biotic variables}

Twenty-nine genera belonging to three subfamilies (Tanypodinae, Chironominae and Orthocladiinae) were recorded in this study. The Paraná subsystem showed the highest values of dominance and the subsystem Ivinhema the

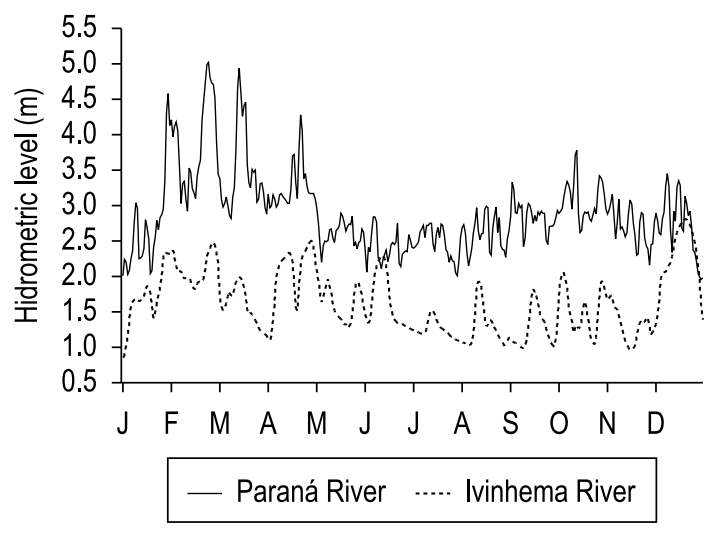

Figure 2. Hidrometric level of the rivers Paraná and Ivinhema from January to December 2003. 
largest number of rare taxa. Polypedilum was the only genus present in all sampling stations, and was dominant in five of them. Chironomus and Goeldichironomus were dominant in Osmar Lake. Tanytarsus was dominant in the Ivinhema River, Pau Véio Backwater and Osmar Lake. Caladomyia, like Tanytarsus, was dominant in three different types of environment (Ivinhema River, Patos Lake
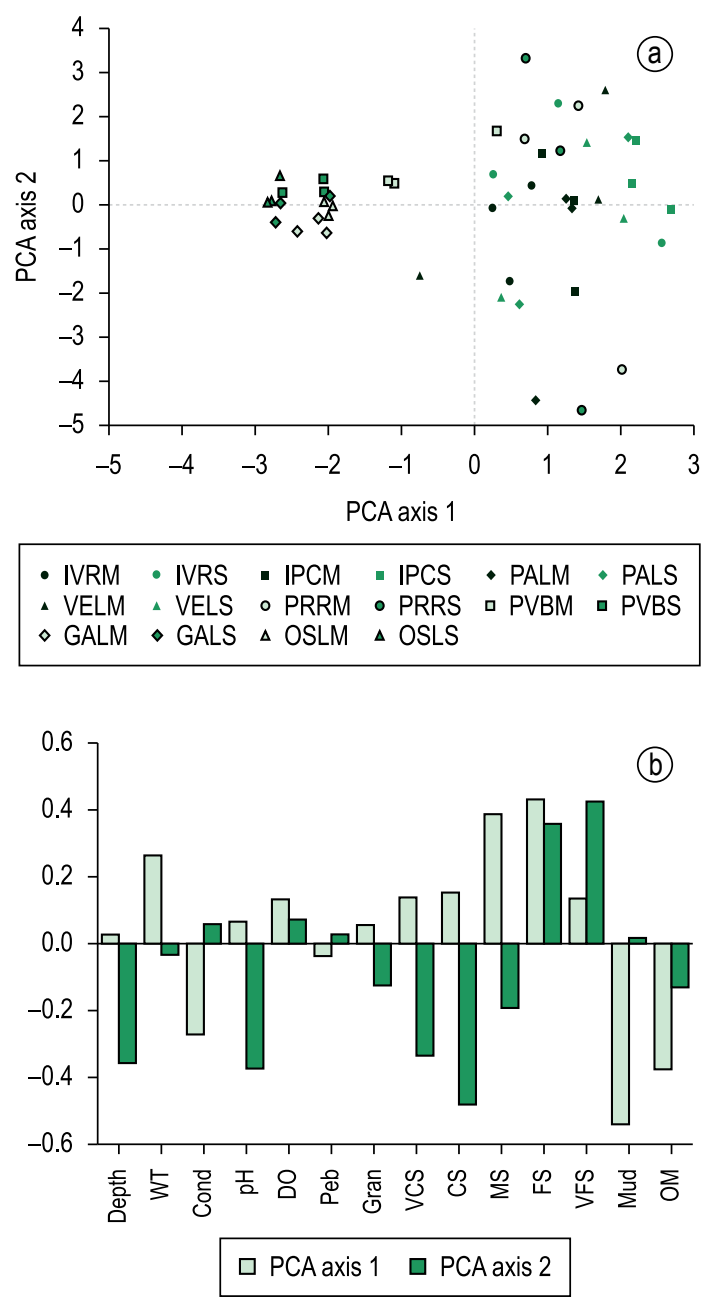

Figure 3. a) Ordination diagram of the first two axis of the PCA, b) eigenvectors of PCA variables. IVRM = Ivinheima River (March); IVRS = Ivinheima River (September); IPCM = Ipoitã Channel (March); IPCS = Ipoitã Channel (September); PALM = Patos Lake (March); PALS = Patos Lake (September); VELM= Ventura Lake (March); VELS = Ventura Lake (September); PRRM = Paraná River (March); PRRS = Paraná River (September); PVBM = Pau Véio Backwater (March); PVBS = Pau Véio Backwater (September); GALM= Garças Lake (March); GALS= Garças Lake (September); OSLM = Osmar Lake (March); OSLS = Osmar Lake (September).WT= water temperature; Cond = conductivity; $\mathrm{DO}=$ dissolved oxygen; $\mathrm{Peb}=$ pebbles; $\mathrm{Gran}=$ granules; $\mathrm{VCS}=$ very coarse sand; $\mathrm{CS}=$ coarse sand; $\mathrm{MS}=$ medium sand; $\mathrm{FS}=$ fine sand; $\mathrm{VFS}=$ very fine sand; $\mathrm{OM}=$ organic matter. and Pau Véio Backwater). The genera Axarus and Cryptochironomus were dominant in the Paraná River (Table 1).

Mean density varied between environments and collection months. The largest variations were observed in the Paraná River subsystem with means close to zero in all environments in March and density peak in the Osmar Lake in September. In the Ivinhema River subsystem the range of variation in density was lower (Figure 5).

The distribution of scores for the first two DCA axes, with eigenvalues of 0.669 (axis 1) and 0.356 (axis 2), showed the formation of two groups (Figure 6), the first formed mainly by the genera Chironomus, Dicrotendipes, Goeldichironomus, and Tanypus found in the Garças and Osmar Lakes and Pau Véio Backwater (Group I), and the second consisting by the other genera, in the Ivinhema River subsystem and in the main channel of the Paraná River (Group II). The two-way ANOVA showed significant differences between groups in the first axis (Sampling stations*Months: $\mathrm{F}_{5,26}=2.79 ; \mathrm{p}=0.03$ ) (Figure 7). DCA ordination considers the composition and density of the taxonomic groups. DCA grouped the main channel of the Paraná River and the subsystem Ivinhema, influenced mainly by the presence of Axarus and Cryptochironomus in both rivers. However, most genera of group II, Djalmabatista, Procladius, Harnischia, Nilothauma, Paralauterboniella, Saetheria, Stenochironomus, Aedokrytus, Cricotopus, Nanocladius, and Thienemanniella occurred only in the Ivinhema River subsystem.

The Chironomidae diversity values $(H)$ varied the most between the sampling stations of the Paraná River subsystem; null values were registered in the Garças and Osmar Lakes in March. In the Ivinhema River subsystem, diversity values varied less between the sampling stations and the highest values were observed in the Ipoitã channel (Figure 8).

\section{Discussion}

In river-floodplain systems, the composition, distribution and diversity of Chironomidae are strictly related to biogeochemical processes and to the high habitat heterogeneity of these ecosystems (Franquet, 1999; Rosin and Takeda, 2007). High percentages of organic matter were observed in the PCA for lakes of the Paraná subsystem; as the water level increased in the Paraná River subsystem in March, a great inflow of allochthonous material reached the environments. The rapid decomposition of this material, influenced by increased temperature, 


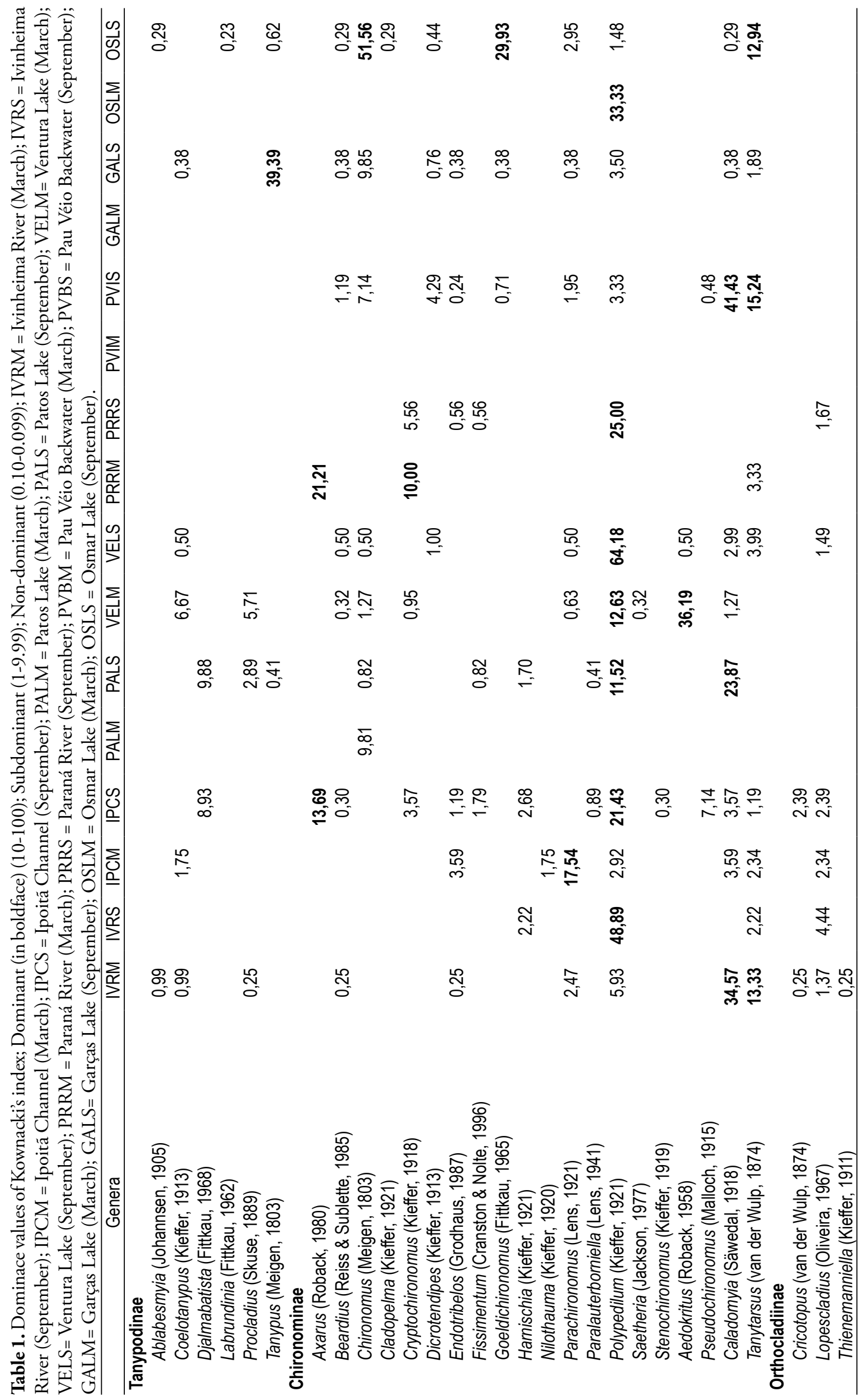


reduced the dissolved oxygen values, which probably resulted in low Chironomidae densities in the lakes of the Paraná River subsystem in the same period. On the other hand, the Ivinhema River subsystem was less affected by this event. As previously mentioned, the Ivinhema River is affected by the fluviometric level of the Paraná River when it is higher than $4.5 \mathrm{~m}$ (Souza-Filho et al., 2004). This level was observed a few times during the year of 2003.

Polypedilum was recorded in all environments, being dominant in six of them. This genus is known for its relative resistance to adverse conditions (Panis et al., 1996) and also for being generalist (Callisto et al., 2000; Santos and Henry, 2001). Polypedilum is usually the most common Chironomidae genus in the environments of the Upper Paraná River floodplain (Higuti et al., 1993; Higuti and Takeda, 2002; Rosin and Takeda, 2007; Rosin et al., 2009).

As evidenced by the DCA, Chironomus, Dicrotendipes, Goeldichironomus, and Tanypus, which formed group I, were the main genera of lakes associated to the Paraná River. These genera are tolerant to wide variety of environmental conditions (Pinder, 1995). The massive presence and dominance (Kownacki index) of Chironomus may be an indicator of impacted environments (Kleine and Trivinho-Strixino, 2005). The lowest diversity values and the highest number of dominant groups in the Paraná subsystem are probably also related to the impacts caused by damming. According to Munn and Brusven (1991) and Takao et al. (2008) the macroinvertebrate assemblage downstream the dams often shows reduction of diversity with low taxon richness and the predominance of particular species.

On the other hand, the Ivinhema River subsystem showed great variety of taxonomic groups and exclusive composition: Djalmabatista, Procladius, Harnischia, Nilothauma, Paralauterboniella, Saetheria, Stenochironomus, Aedokrytus, Cricotopus, Nanocladius, and Thienemanniella. This fact is probably related to the environmental conditions, typical of more conserved areas. The strong presence of genera of Orthocladiinae in the Ivinhema River subsystem reinforces such evidence, because this subfamily is considered typical of areas that have undergone little impact (Roque et al., 2000).

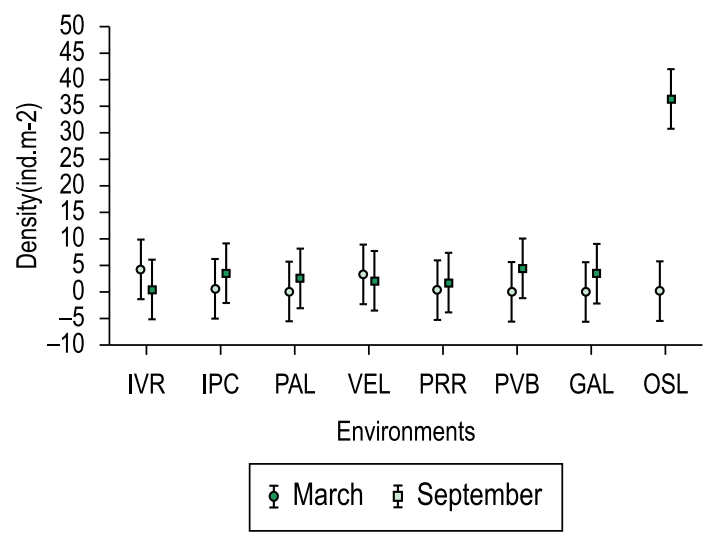

Figure 5. Mean density \pm SE of Chironomidae larvae in the environments: IVR = Ivinhema River; IPC = Ipoitá channel; PAL = Patos Lake; VEL= Ventura Lake; PRR = Paraná River; PVB = Pau Véio Backwater; GAL = Garças Lake; OSL = Osmar Lake, in March and September 2003.
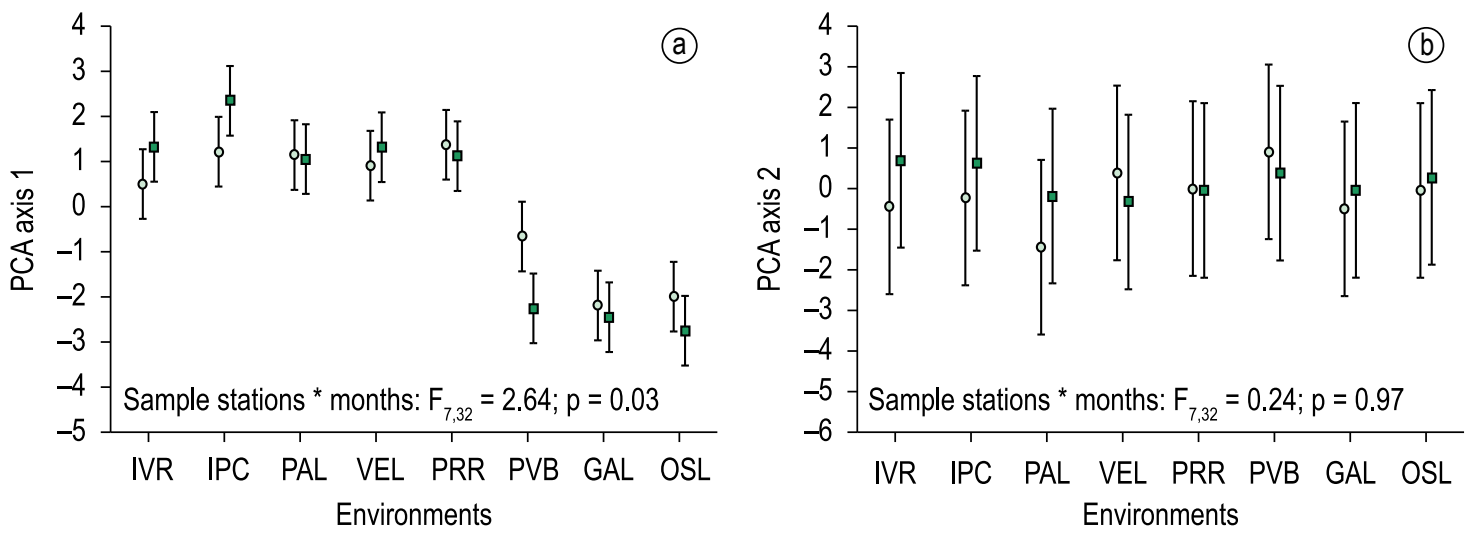

§. March 도 September

Figure 4. Mean \pm SE of the two-way ANOVA with axis 1a) and 2b) of PCA for the environments: IVR = Ivinhema River; IPC = Ipoitã channel; PAL = Patos Lake; VEL= Ventura Lake; PRR = Paraná River; PVB = Pau Véio Backwater; GAL = Garças Lake; OSL = Osmar Lake, in March and September 2003. 
Rodrigues et al. (2009) mentioned that the potamoplankton in the Ivinhema River system is characterized by a community typical of nondammed rivers, with low densities of each taxon and high proportions of rare species. Through the observed results, the Chironomidae community in the Ivinhema River subsystem follows the same pattern mentioned above.

The Ipoitã channel (Ivinhema subsystem) was the station with the highest diversity index, probably due to the fact that this channel has great physical heterogeneity, proportioned by the presence of macrophyte banks (Eichhornia spp.) and submerged branches, providing great quantity of microhabitats. In addition, areas with riparian vegetation, such as the Ipoitã Channel, maintain higher diversity of Chironomidae than deforested areas (HenriquesOliveira et al., 1999).

Results showed differences in the Chironomidae community structure between the Paraná and Ivinhema subsystems. The irregularity of floods caused by dams in the Paraná River may make the aquatic communities more susceptible to changes, such as reduced diversity and density, when exposed to events like the flood pulses. Probably reflecting this situation, we observed low density and diversity
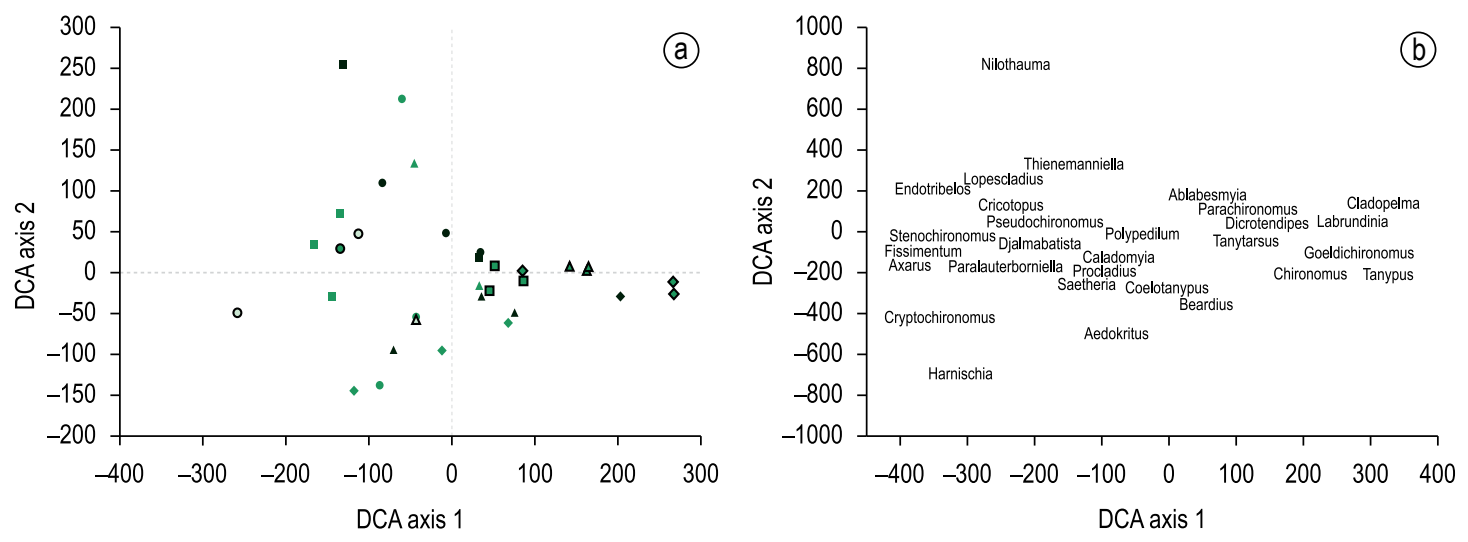

Figure 6. Ordination diagram of the first two axis of the DCA based on species composition and abundance of Chironomidae larvae in the stations. a) Ordination of the stations, b) ordination of the genera; IVRM = Ivinheima River (March); IVRS = Ivinheima River (September); IPCM = Ipoitã Channel (March); IPCS = Ipoitã Channel (September); PALM = Patos Lake (March); PALS = Patos Lake (September); VELM= Ventura Lake (March); VELS= Ventura Lake (September); PRRM = Paraná River (March); PRRM = Paraná River (September); PVBS = Pau Véio Backwater (September); GALS= Garças Lake (September); OSLM = Osmar Lake (March); OSLS = Osmar Lake (September).

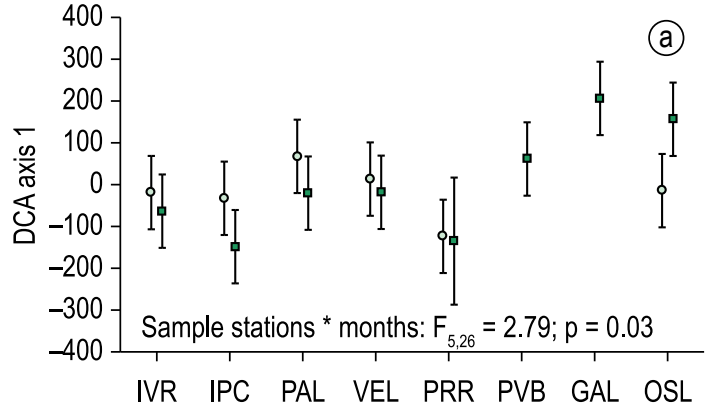

Environments

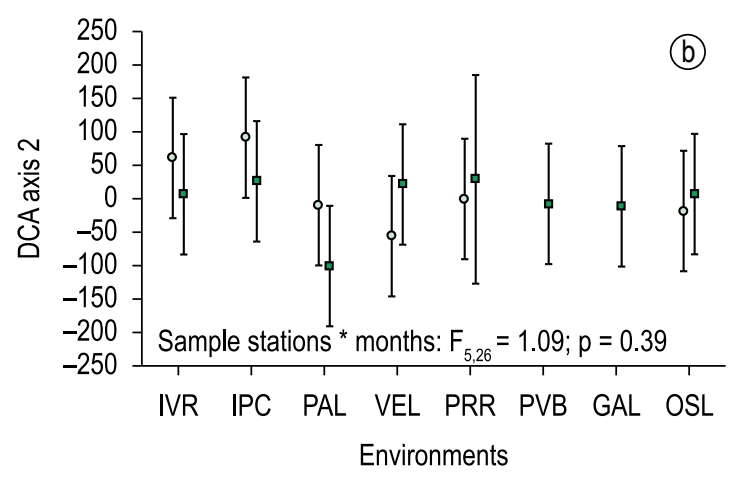

Environments

\$ March 页 September

Figure 7. Mean $\pm S E$ of the two-way ANOVA with axis 1a) and 2b) of DCA for the environments: IVR = Ivinhema River; $\mathrm{IPC}=$ Ipoitã channel; $\mathrm{PAL}=$ Patos Lake; VEL= Ventura Lake; $\mathrm{PRR}=$ Paraná River; $\mathrm{PVB}=$ Pau Véio Backwater; GAL $=$ Garças Lake; OSL = Osmar Lake, in March and September 2003. 


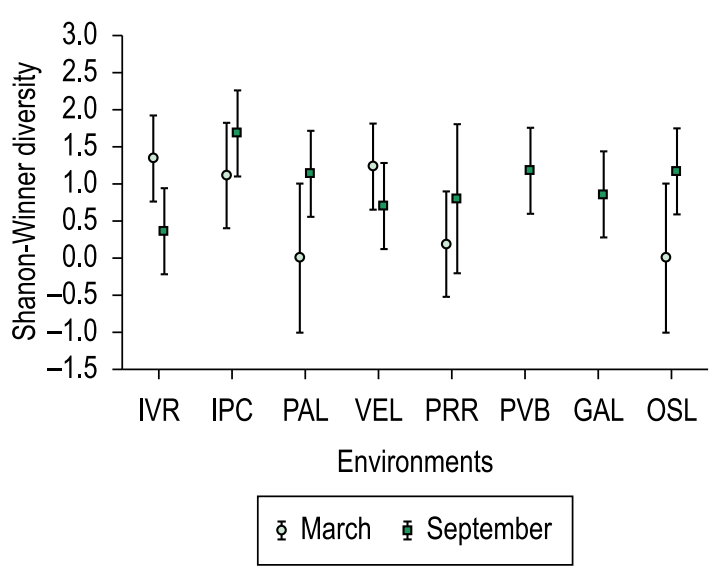

Figure 8. Mean \pm SE of Shannon-Wiener diversity in the environments: IVR = Ivinhema River; IPC = Ipoitã channel; PAL = Patos Lake; VEL= Ventura Lake; PRR = Paraná River; PVB = Pau Véio Backwater; GAL = Garças Lake; OSL $=$ Osmar Lake, in March and September 2003.

of Chironomidae in Paraná River subsystem. Moreover, the composition of Chironomidae in the Paraná subsystem was constituted mainly by generalist and tolerant genera. On the other hand, in the subsystem Ivinhema we observed more variety of taxa and, in general, spatial and temporal distribution of the Chironomidae more homogeneous compared with the distribution of the Chironomidae community in the Paraná subsystem. The Ivinhema River is a dam-free environment and presents more regular floods, with more periodicity; it must be a decisive factor for the maintenance of the community structure, because during the historical formation of their life cycles, aquatic species developed strategies that depend on the natural flood regime (Bunn and Arthington, 2002). Finally, the greatest diversity, lowest values of dominance and exclusive taxonomic composition in the Ivinhema River subsystem could be reflecting a less degraded environment, demonstrating that the preservation of areas such as this system is fundamental for the maintenance of the diversity of Chironomidae.

\section{Acknowledgements}

The authors acknowledge the financial support of LTER (Long Term Ecological Research) project, by the CNPq (Conselho Nacional de Pesquisa em Ciência e Tecnologia), physics and chemistry laboratory of Nupélia for furnishing water quality data, ANA (Agência Nacional das Águas) and Itaipu Binacional for the hydrometric level data and Jaime Luiz Lopes Pereira for making the map.

\section{References}

ABUJANRA, F., AGOSTINHO, AA. and HAHN, NS. 2009. Effects of the flood regime on the body condition of fish of different trophic guilds in the Upper Paraná River floodplain, Brazil. Revista Brasileira de Biologia = Brazilian Journal of Biology, vol. 69, no. 2 (Suppl.), p. 469-479.

AGOSTINHO, AA., PELICICE, FM. and GOMES, LC. 2008. Dams and the fish fauna of the Neotropical region: impacts and management related to diversity and fisheries. Revista Brasileira de Biologia $=$ Brazilian Journal of Biology, vol. 68, no. 4 (Suppl.), p. 1119-1132.

ARMITAGE, PD. and PARDO, I. 1995. Impact assessment of regulation at the reach level using macroinvertebrate information from mesohabitats. Regulated Rivers: Research and Management, vol. 10, p. $147-158$.

BUNN, SE. and ARTHINGTON, AH. 2002. Basic principles and ecological consequences of altered flow regimes for aquatic biodiversity. Environment \& Management, vol. 30, no. 4, p. 492-507.

CALLISTO, M., BARBOSA, FA. and MORENO, P. 2000. Macrobenthic diversity on different habitats in an altitudinal lake surrounded by Eucalyptus plantations and secondary Atlantic Forest (southeast Brazil). Acta Limnologica Brasiliensia, vol. 12, no. 1, p. 55-61.

EPLER, JH. 1995. Identification manual for the larval Chironomidae of Florida. Revised edition. Tallahassee: Florida department of environmental regulation. $319 \mathrm{p}$.

FERRINGTON, LC. 2008. Global diversity of nonbiting midges (Chironomidae; Insecta-Diptera) in freshwater. Hydrobiologia, vol. 595, no. 1, p. 447-455.

FRANQUET, E. 1999. Chironomid assemblage of a Lower-Rhône dike field: relationships between substratum and biodiversity. Hydrobiologia, vol. 397, p. 121-131.

GALDEAN, N., CALLISTO, M. and BARBOSA FAR. 2000. Lotic ecosystems of Serra do Cipó, southeast Brazil: water quality and a tentative classifcation based on the benthic macroinvertebrate community. Aquatic Ecosystem Health and Management, vol. 3, p. 545-552.

GREENWOOD, MT., BICKERTON, MA. and PETTS GE. 1999. Channel changes and invertebrate faunas below Nant-Y-Moch Dam, river Rheidol, Wales, UK: 35 years on. Regulated Rivers: Research and Management, vol. 15, p. 99-112.

HAYAKAWA, EH. 2007. Análise da variabilidade espacial e temporal dos sedimentos suspensos do Alto rio Paraná via imagens orbitais: regiāo de porto São José - PR. Maringá, PR: Universidade Estadual de Maringá UEM, 2007. [Master thesis in Geography]. 
HENRIQUES-OLIVEIRA, AL., SANSEVERINO, AM. and NESSIMIAN, JL. 1999. Larvas de Chironomidae (Insecta:Diptera) de substrato rochoso em dois rios em diferentes estados de preservação na Mata Atlântica, RJ. Acta Limnologica Brasiliensia, vol. 11, no. 2, p. 17-28.

HIGUTI, J. and TAKEDA, AM. 2002. Spatial and temporal variation in of Chironomid larval (Diptera) in two Lakes and two tributaries of the Upper Paraná River floodplain, Brazil. Revista Brasileira de Biologia = Brazilian Journal of Biology, v. 62, no. 4, p. 807-818.

HIGUTI, J., TAKEDA, AM. and PAGGI, AC. 1993. Distribuição espacial das larvas de Chironomidae (INSECTA, DIPTERA) do rio Baía (MS-Brasil). Revista Unimar, vol. 15, p. 65-81.

KLEINE, P. and TRIVINHO-STRIXINO, S. 2005. Chironomidae and other aquatic macroinvertebrates of a first order stream: community response after habitat fragmentation. Acta Limnologica Brasiliensia, vol. 17, no. 1, p. 81-90.

KOWNACKI, A. 1971. Taxocens of Chironomidae in streams of the Polish High Tatra Mts. (Str.). Acta Hydrobiologica, vol. 13, no. 4, p. 439-464.

MUNN, MD. and BRUSVEN, MA. 1991. Benthic macroinvertebrate communities in nonregulated and regulated waters of the Clearwater River, Idaho, U.S.A. Regulated Rivers: Research and Management, vol. 6, p. 1-11.

PANIS, LI., GODDEERIS, B. and VERHEYEN, R. 1996. On the relationship between vertical microdistribution and adaptations to oxygen strees in litoral Chironomidae (Diptera). Hydrobiologia, vol. 318, p. 61-67.

PAULETO, GM., VELHO, LFM., BUOSI, PRB., BRÃO, AFS., LANSAC-TÔHA, FA. and BONECKER, CC. 2009. Spatial and temporal patterns of ciliate species composition (Protozoa: Ciliophora) in the plankton of the Upper Paraná River floodplain. Revista Brasileira de Biologia = Brazilian Journal of Biology, vol. 69, no. 2 (Suppl.), p. 517-527.

PINDER, LCV. 1995. The habitats of Chironomidae larvae. In ARMITAGE, P., CRANSTON, PS. and PINDER, LCV., eds. The Chironomidae, bioloy and ecology of non-biting midges. London: Chapman and Hall. p. 107-117.

ROCHA, PC., SANTOS, ML. and SOUZA-FILHO, EE. 2001. Alterações no regime hidrológico do alto rio Paraná como resposta ao controle de descargas efetuado por grandes barramentos a montante. In VIII Encuentro de Geógr. de América Latina. Santiago, Chile.

RODRIGUES, LC., TRAIN, S., BOVO-SCOMPARIN, VM., JATI, S., BORSALLI, CCJ. and MARENGONI, E. 2009. Interannual variability of phytoplankton in the main rivers of the Upper Paraná River floodplain, Brazil: influence of upstream reservoirs. Revista
Brasileira de Biologia = Brazilian Journal of Biology, vol. 69, no. 2 (Suppl.), p. 501-516.

ROQUE, FO., CORBI, JJ. and TRIVINHO-STRIXINO, S. 2000. Consideraçóes sobre a utilização de larvas de Chironomidae (Diptera) na avaliaçáo da qualidade da água de córregos do Estado de São Paulo. In: ESPÍNDOLA, ELG., PASCHOA, CMRB., ROCHA, O., BOHRER, MBC. and OLIVEIRA NETO, AL., eds. Ecotoxicologia-Perspectivas para o século XXI. São Carlos: RiMa, p.115-126.

ROSENBERG, DM. and RESH, VH. 1996. Use of aquatic insects in biomonitoring. In: MERITT RW. and CUMMINS, KW., eds. An Introduction to the Aquatic Insects of North America. 3rd ed. Dubuque, IA: Kendall/Hunt Publishing Co. p. 87-99.

ROSIN, GC. and TAKEDA, AM. 2007. Larvas de Chironomidae (Diptera) da planície de inundação do alto rio Paraná: distribuição e composição em diferentes ambientes e fases hídricas. Acta Scientiarum Biological Sciences, vol. 29, no. 1, p. 57-63.

ROSIN, GC., OLIVEIRA-MANGAROTTI, DP., TAKEDA, AM. and BUTAKKA, CMM. 2009. Consequences of a dam construction upstream from the Upper Paraná River floodplain (Brazil): temporal analysis of the Chironomidae community over an eight-year period. Revista Brasileira de Biologia $=$ Brazilian Journal of Biology, vol. 69, no. 2 (Suppl.), p. 591-608.

SANTOS, CM. and HENRY, R. 2001. Composição, distribuição e abundância de Chironomidae (Diptera, Insecta) na represa de Jurumirim (rio ParanapanemaSP). Acta Limnologica Brasiliensia, vol. 13, no. 2, p. 99-115.

SHANNON, CE. and WEAVER, W. 1963. The mathematical theory of communication. Illinois: University Press Urbana. 125 p.

SOUZA FILHO, EE., ROCHA, PC., COMUNELLO, E. and STEVAUX, JC. 2004. Effects of the Porto Primavera Dam on physical environment of the dowstream floodplain. In: THOMAZ, SM., AGOSTINHO, AA. and HAHN, NS., eds. The Upper Paraná River and its floodplain: physical aspects, ecology and conservation. Leiden: Backhuys Publishers. p. 55-74.

SOUZA-FILHO, EE. and STEVAUX, JC. 1997. Geologia e Geomorfologia do complexo rio Baia, Curutuba, Ivinheima. In: VAZZOLER, AEAM., AGOSTINHO, AA. and HAHN, NS., eds. $A$ Planície de Inundação do Alto Rio Paraná: Aspectos Físicos, Biológicos e Socio-econômicos. Maringá: EDUEM. p. 3-46.

STEVAUX, JC., SOUZA-FILHO, EE. and JABUR, IC. 1997. A história quaternária do rio Paraná em seu alto curso. In: VAZZOLER, AEAM., AGOSTINHO, AA. and HAHN, NS., eds. A Planície de Inundação do Alto Rio Paraná: Aspectos Físicos, Biológicos e Socio-econômicos. Maringá: EDUEM. p. 47-72. 
STEVENS, LE., SHANNON, JP. and BLINN, DW. 1997. Colorado River benthic ecology in Grand Canyon, Arizona, USA: dam, tributary and geomorphological influences. Regulated Rivers: Research and Management, vol. 13, p. 129-149.

STOREY, AW., EDWARD, DH. and GAZEY, P. 1991. Recovery of aquatic macroinvertebrate assemblages downstream of the canning dam, western Australia. Regulated Rivers: Research and Management, vol. 6, p. 213-334.

TAKAO, A., KAWAGUCHI, Y., MINAGAWA, T., KAYABA, Y. and MORIMOTO, Y. 2008. The relationships between benthic macroinvertebrates and biotic and abiotic environmental characteristics downstream of the Yahagi Dam, Central Japan, and the state change caused by inflow from a tributary. River Research and Applications, vol. 24, p. $580-597$.
THOMAZ, SM., PAGIORO, TA., BINI, LM., ROBERTO, MC. and ROCHA, RRA. 2004. Limnological characterization of the aquatic environments and the influence of hydrometric levels. In: THOMAZ, SM., AGOSTINHO, AA. and HAHN, NS., org. The upper Paraná River and its floodplain:Physical Aspects, Ecology and Conservation. Leiden: Backhuys Publishers. p. 75-102.

TRIVINHO-STRIXINO, S. and STRIXINO, G. 1995. Larvas de Chironomidae (Diptera) do Estado de São Paulo. Guia de Identificação e Diagnose dos Gêneros. São Carlos: Universidade Federal de São Carlos.

VINSON, MR. 2001. Long-term dynamics of an invertebrate assemblage downstream from a large dam. Ecological Applications, vol. 11, p. 711-730.

WENTWORTH, CK. 1922. A scale of grade and class trems for clastic sediments. Journal of Geology, vol. 30, p. 377-392. 